\title{
L4 FRACTURES, BIOMECHANICS OF CURE FORETOLD
}

\author{
FRATURAS L4, BIOMECÂNICA DE UMA CURA ANUNCIADA \\ FRACTURA DE L4, BIOMECÁNICA DE UNA CURACIÓN ANUNCIADA \\ Daniel Alberto Ramírez Islas ${ }^{1}$, José María Jiménez Ávila ${ }^{1}$
}

\begin{abstract}
Objectives: To analyze the clinical and radiographic outcomes in fracture of the fourth lumbar vertebra, under conservative or surgical treatment. Methods: Patients diagnosed with $L 4$ fracture with or without neurological injury were studied and to whom conservative or surgical treatment was provided. Radiographic measurements were performed taking into account the kyphosis angle, the sagittal index, loss of vertebral body height, percentage of canal occlusion and height compression percentage. Results: Twenty-five patients were treated, five conservatively and 20 surgically. The vertebral kyphosis angle in both groups was $12^{\circ}$, no regional kyphosis was present, the sagittal index was 11.9 (Farcy), the loss of vertebral body height was $53.17 \%$, the percentage of canal occlusion was $23 \%$ and the height compression percentage was $38.06 \%$. The residual pain according to the visual analog scale was two in both groups. Conclusions: Patients with a fractured $L 4$ have a satisfactory outcome with both treatments, the height of the vertebral body remains the same, the lordosis is preserved and therefore the sagittal balance, allowing recovering the mechanical functions of the spine as opposed to other segment fractures.
\end{abstract}

Keywords: Spine; Spinal fractures; Lumbar vertebrae; Biomechanical phenomena.

\section{RESUMO}

Objetivos: Analisar os resultados clínicos e radiográficos em fratura da quarta vértebra lombar, em tratamento consenvador ou cirúrgico. Métodos: Foram estudados pacientes com diagnóstico de fratura L4 com ou sem lesão neurológica, que receberam tratamento conservador ou cirúrgico. Medições radiográficas foram realizadas tendo em conta o ângulo de cifose, o índice sagital, a perda da altura do corpo vertebral, o percentual de oclusão do canal e a porcentagem de compressão da altura. Resultados: Dos vinte e cinco pacientes, cinco foram tratados de forma consenadora e 20 cirurgicamente. O ângulo da cifose vertebral em ambos os grupos foi de $12^{\circ}$, não houve presença de cifose regional, o índice sagital foi 11,92 (Farcy), a perda de altura do corpo vertebral foi 53,17\%, o percentual de oclusão do canal foi $23 \%$ e a porcentagem de compressão de altura foi 38,06\%. A dor residual de acordo com a escala visual analógica (VAS) foi de dois em ambos os grupos. Conclusões: Os pacientes com fratura de L4 têm resultado satisfatório com ambos os tratamentos, a altura do corpo vertebral permanece a mesma, a lordose é preservada, assim como o equilíbrio sagital, o que permite a recuperação das funções mecânicas da coluna vertebral, ao contrário das fraturas de outros segmentos.

Descritores: Coluna vertebral; Fraturas da coluna vertebral; Vértebras lombare; Fenômenos biomecânicos.

\section{RESUMEN}

Objetivos: Analizar la evolución clínico-radiográfica en fracturas de la cuarta vértebra lumbar, bajo tratamiento conservador o quirúrgico. Métodos: Se estudiaron pacientes diagnosticados con fractura de L4 con o sin lesión neurológica, a quienes se brindó tratamiento consenvador o quirúrgico. Se realizaron mediciones radiográficas tomando en cuenta el ángulo de cifosis, el índice sagital de Farcy, pérdida de la altura del cuerpo vertebral, ocupación del canal y porcentaje de compresión. Resultados: Se trataron 25 pacientes, cinco conservadoramente y 20 con tratamiento quirúrgico. El ángulo de cifosis vertebral en ambos grupos fue de $12^{\circ}$, no se presentó cifosis regional, el índice de Farcy de 11,92, la pérdida de la altura del cuerpo vertebral fue de 53,17\%, la ocupación del canal de 23\% y el porcentaje de compresión de $38,06 \%$. El dolor residual según la escala visual análoga fue de dos en ambos grupos. Conclusiones: Los pacientes que presentan una fractura en L4 tienen una evolución satisfactoria con ambos tratamientos, se mantiene la altura del cuerpo vertebral, se conserva la lordosis y por lo tanto el balance sagital, lo que permite recuperar las funciones mecánicas de la columna vertebral en su conjunto a diferencia de fracturas en otros segmentos.

Descriptores: Columna Vertebral; Fracturas de la columna vertebral; Vértebras lumbares; Fenômenos biomecánicos.

\section{INTRODUCTION}

Fractures of the lower spine constitute $14 \%$ of all thoracolumbar lesions, ${ }^{1}$ and are the result of high-impact traumas. ${ }^{2}$

There are unique anatomical characteristics and specific biomechanics in the lumbar segment (L4-L5) that influence the response to trauma, and can justify different treatment approaches in this type of fracture. ${ }^{3}$

Its natural lordosis allows the center of gravity to fall posterior to the center of the vertebral body of $L 4$ (Figure 1), making lower lumbar fractures less susceptible to collapse and kyphosis, which is common in fractures of the thoracolumbar joint (T11-T12). ${ }^{4}$ Neurological complications are limited by an ample neural canal, making the cauda equina less susceptible to injury, and giving a higher potential for its recovery. ${ }^{5}$ Finally, the location of $L 5$ below the edge of the superior portion of the pelvis and its lumbar-sacroiliac ligaments creates a stable environment for the infrequent lesions of this vertebra. ${ }^{6}$ (Figure 2) The functional importance of the mobility of the lumbar spine leads us to limit the extent of the fixation and preserve the mobile segments during the treatment. ${ }^{7}$

1. Centro Médico Nacional de Occidente, Hospital de Especialidades, Instituto Mexicano del Seguro Social. Guadalajara, Jalisco, Mexico.

Study conducted at theTraumatology and Orthopedics Service, Hospital de Especialidades, Centro Médico Nacional de Occidente. Guadalajara, Jalisco, Mexico. Correspondence: Avenida Belisario Domínguez 1000, Col. Belisario Domínguez, Guadalajara, Jalisco. 44329. dan.islas7@gmail.com, josemajimeneza@hotmail.com. 


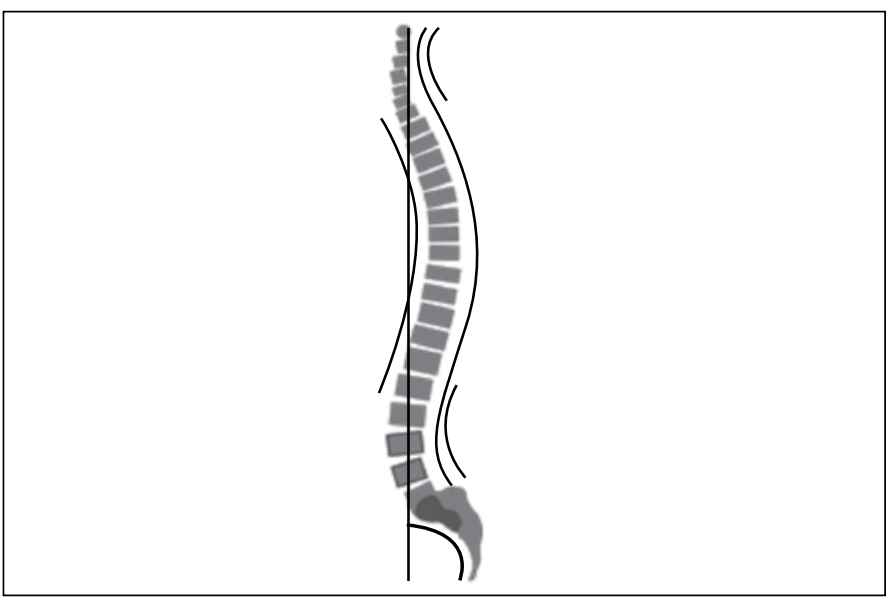

Figure 1. Center of gravity posterior to the $L 4$ body.

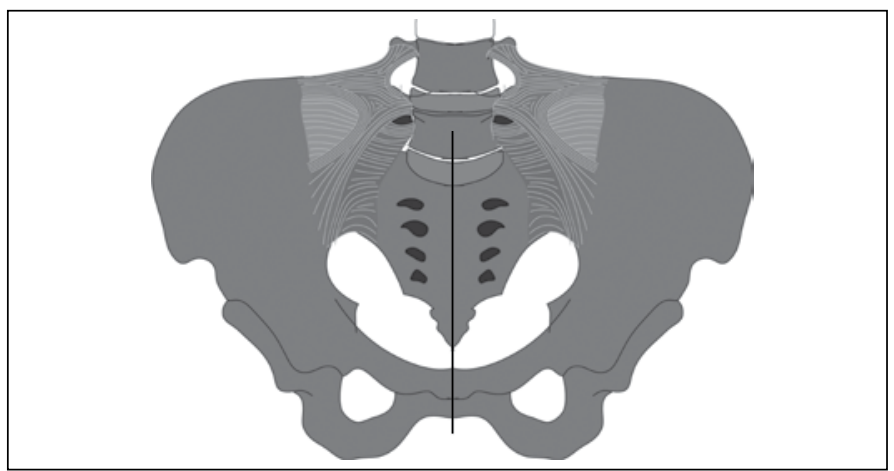

Figure 2. Stability of $L 4$ and $L 5$ by their lumbar iliosacral ligaments and their location below the upper portion of the pelvis.

Although widely studied, the optimal treatment of thoracolumbar fractures remains controversial. The unique characteristics of the lower spine, and the lack of literature on fractures in this region, constitute a challenge when making therapeutic decisions. ${ }^{1}$

\section{METHOD}

The study consisted of patients diagnosed with fracture of $L 4$ (Figures 3 and 4), with or without neurological lesion, submitted to conservative treatment or to surgery with transpedicular instrumentation, posterior release and/or posterolateral fusion, in the period January 2010 to January 2013, at the Hospital de Especialidades Centro Médico Nacional de Occidente, with one-year follow-up.

Data were gathered in relation to age, sex, type of fracture according to the new AO Spine classification of injuries of the thoracic and lumbar spine, ASIA (American Spine Injury Association), as well as residual pain at the end of follow-up, according to the visual analog scale (VAS). Radiographic measurements were performed, taking into account the kyphosis angle, which includes the vertebral kyphosis angle (VK) and the regional kyphosis angle (RK), the sagittal index (SI; Farcy), loss of vertebral body height (\% LVBH), occupation of the canal (\% OC) and percentage of compression (\% Comp).

\section{RESULTS}

A total of 25 patients with L4 fracture were studied: 4 women (16\%), and 21 men (84\%). The average age of the patients was 38.2 years, with s.d. of 17.2. According to the $\mathrm{AO}$ classification of injuries of the thoracic and lumbar spine, we found 1 (4\%) patient with classification $\mathrm{A} 0$, one (4\%) with $\mathrm{A} 1$, six (24\%) with $\mathrm{A} 2$, eight (32\%) with $\mathrm{A} 3$, and nine $(36 \%)$ with $\mathrm{A} 4$. Of the total, five $(20 \%)$ received conservative treatment and $20(80 \%)$ received surgical treatment. (Figures 5 and 6 )

The vertebral kyphosis angle was, on average, $12^{\circ}$; the regional kyphosis angle was negative, which means that it did not present signs

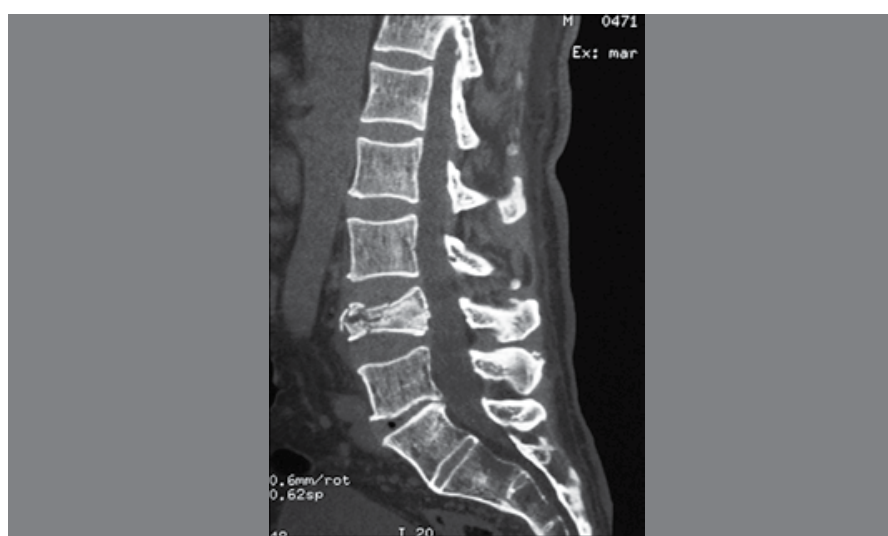

Figure 3. Sagittal section of computed tomography with L4 fracture.

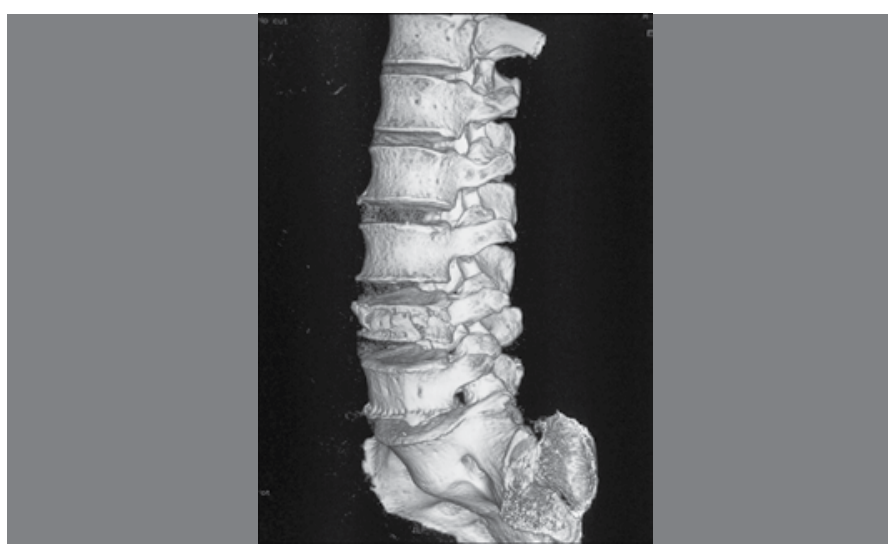

Figure 4. 3D reconstruction of the L4 vertebral fracture.

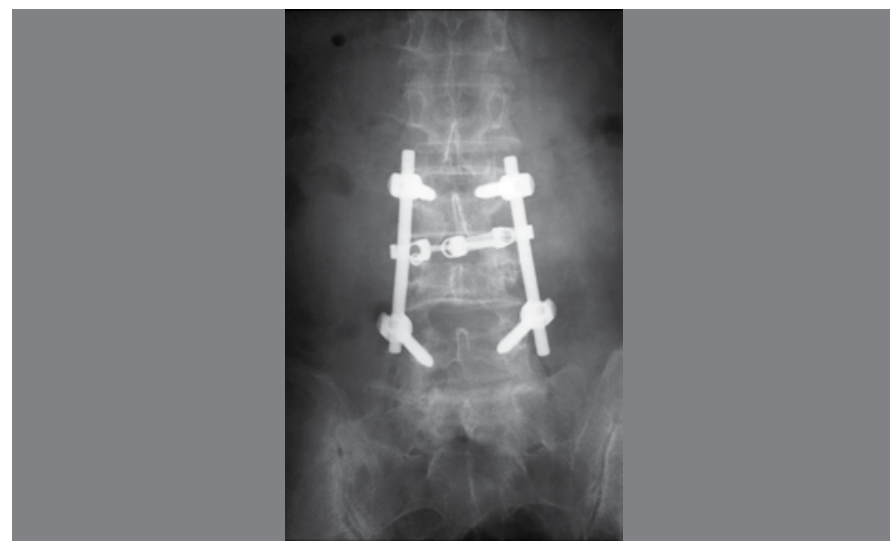

Figure 5. AP view of the L3-L5 posterior instrumentation, by L4 fracture.

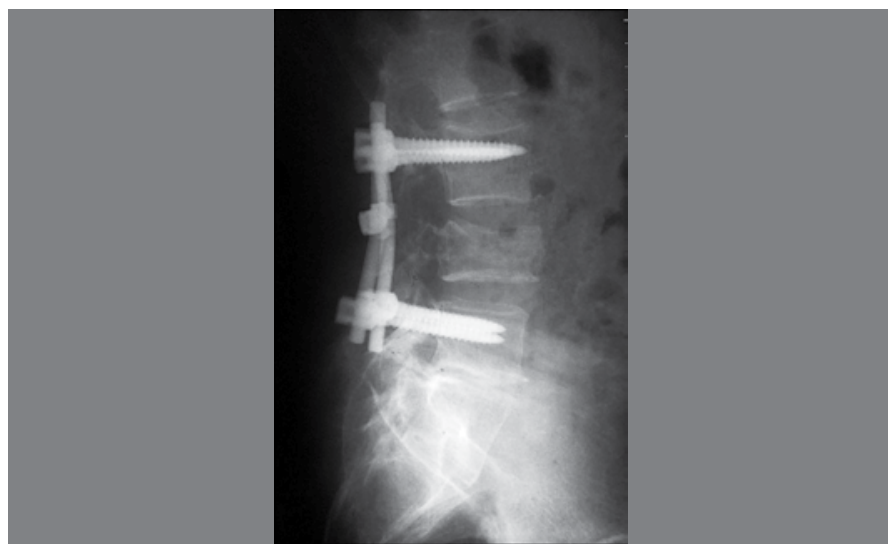

Figure 6. Lateral view of L3-L5 posterior instrumentation, by L4 fracture. 
of preservation of lordosis the segment, sagittal index (Farcy) of 11.92, loss of vertebral body height of $53.17 \%$, occupation of the canal of $23 \%$, and percentage of compression of $38.06 \%$. The average residual pain score was 2 according to the Visual Analog Scale (VAS). (Table 1)

In the group treated surgically, measurements at one year of follow-up showed a vertebral kyphosis angle of $12^{\circ}$, regional kyphosis null, sagittal Index (Farcy) of 11.54, loss of vertebral body height of $51.8 \%$, occupation of the canal of $23.12 \%$ and percentage of compression of $37.16 \%$. The residual pain score was 2 according to the VAS in all the patients. (Table 2)

In the group treated conservatively we found a vertebral Kyphosis angle of $13^{\circ}$, regional kyphosis null, sagittal index (Farcy) of 12.18, loss of vertebral body height of $55.37 \%$, occupation of the canal of $22.64 \%$ and percentage of compression of $37.61 \%$. The average residual pain according to the VAS score was 2. (Table 3)

Table 1. Demographic data in patients with $L 4$ fractures.

\begin{tabular}{|c|c|c|c|c|c|c|}
\hline \multicolumn{2}{|c|}{ Variables } & Abs. Freq. & Rel. Freq. & \begin{tabular}{|l|} 
Variables \\
\end{tabular} & Average & SD \\
\hline \multirow{2}{*}{ Sex } & Female & 4 & $16 \%$ & KV & 12 & 6 \\
\hline & Male & 21 & $84 \%$ & RK & 0 & 0 \\
\hline \multirow{5}{*}{ AO Spine } & $\mathrm{AO}$ & 1 & $4 \%$ & SI & 11.92 & 1.68 \\
\hline & A1 & 1 & $4 \%$ & \%LVBH & 53.17 & 16.85 \\
\hline & A2 & 6 & $24 \%$ & $\% \mathrm{OC}$ & 23 & 26.37 \\
\hline & A3 & 8 & $32 \%$ & $\%$ Comp & 38.06 & 13.84 \\
\hline & A4 & 9 & $36 \%$ & VAS & 2.08 & 0.08 \\
\hline \multirow{5}{*}{ ASIA } & A & 0 & $0 \%$ & & & \\
\hline & B & 0 & $0 \%$ & & & \\
\hline & $\mathrm{C}$ & 1 & $4 \%$ & & & \\
\hline & D & 1 & $4 \%$ & & & \\
\hline & $E$ & 23 & $92 \%$ & & & \\
\hline \multirow{2}{*}{ Treatment } & Conservative & 5 & $20 \%$ & & & \\
\hline & Surgical & 20 & $80 \%$ & & & \\
\hline
\end{tabular}

$(\mathrm{N}=25)$.

Table 2. Demographic data in patients with $L 4$ fractures submitted to surgical treatment.

\begin{tabular}{|c|c|c|c|c|c|c|}
\hline \multicolumn{2}{|c|}{ Variables } & Abs. Freq. & Rel. Freq. & Variables & Average & SD \\
\hline \multirow{2}{*}{ Sex } & Female & 4 & $20 \%$ & KV & 12 & 6 \\
\hline & Male & 16 & $80 \%$ & RK & 0 & 0 \\
\hline \multirow{5}{*}{ AO Spine } & $\mathrm{A} 0$ & 1 & $5 \%$ & SI & 11.54 & 1.68 \\
\hline & $\mathrm{A} 1$ & 1 & $5 \%$ & \%LVBH & 51.8 & 16.85 \\
\hline & $\mathrm{A} 2$ & 5 & $25 \%$ & $\% \mathrm{OC}$ & 23.12 & 26.37 \\
\hline & $\mathrm{A} 3$ & 5 & $25 \%$ & \%Comp & 37.16 & 13.84 \\
\hline & A4 & 8 & $40 \%$ & VAS & 2.03 & 0.86 \\
\hline \multirow{5}{*}{ ASIA } & A & 0 & $0 \%$ & & & \\
\hline & B & 0 & $0 \%$ & & & \\
\hline & $\mathrm{C}$ & 1 & $5 \%$ & & & \\
\hline & D & 1 & $5 \%$ & & & \\
\hline & $E$ & 18 & $90 \%$ & & & \\
\hline
\end{tabular}

$(\mathrm{N}=20)$.

\section{REFERENCES}

1. Magerl F, Aebi M, Gertzbein SD, Harms J, Nazarian S. A comprehensive classification of thoracic and lumbar injuries. Eur Spine J. 1994;3(4):184-201.

2. Sansur $\mathrm{CH}$, Shaffrey Cl. Diagnosis and management of low lumbar burst fractures. Semin Spine Surg. 2010;22(1):33-7.

3. Schouten R, Fisher CG. Fusion for Lower Lumbar (L3-L5) Fractures: Surgical Indications and Techniques. Semin Spine Surg. 2011;23(4):249-56.

4. Al-Khalifa FK, Adjei N, Yee AJ, Finkelstein JA. Patterns of collapse in thoracolumbar burst fractures. J Spinal Disord Tech. 2005:18(5):410-2.

5. Kingwell SP, Noonan VK, Fisher CG, Graeb DA, Keynan O, Zhang H, et al. Relationship of neural axis level of injury to motor recovery and health-related quality of life in patients with a thoracolumbar spinal injury. J Bone Joint Surg Am. 2010;92(7):1591-9.
Table 3. Demographic data in patients with $L 4$ fracture submitted to conservative treatment.

\begin{tabular}{|c|c|c|c|c|c|c|}
\hline \multicolumn{2}{|c|}{ Variables } & Abs. Freq. & Rel. Freq. & Variables & Average & SD \\
\hline \multirow{2}{*}{ Sex } & Female & 0 & $0 \%$ & VK & 13 & 6 \\
\hline & Male & 5 & $100 \%$ & RK & 0 & 0 \\
\hline \multirow{5}{*}{ AO Spine } & $\mathrm{A} 0$ & 0 & $0 \%$ & $\mathrm{SI}$ & 12.18 & 1.82 \\
\hline & $\mathrm{A} 1$ & 0 & $0 \%$ & \%LVBH & 55.37 & 15.27 \\
\hline & $\mathrm{A} 2$ & 1 & $20 \%$ & $\% \mathrm{OC}$ & 22.64 & 28.45 \\
\hline & $\mathrm{A} 3$ & 3 & $60 \%$ & \%Comp & 37.61 & 13.02 \\
\hline & A4 & 1 & $20 \%$ & VAS & 2.00 & 1 \\
\hline \multirow{5}{*}{ ASIA } & $\mathrm{A}$ & 0 & $0 \%$ & & & \\
\hline & $B$ & 0 & $0 \%$ & & & \\
\hline & $\mathrm{C}$ & 0 & $0 \%$ & & & \\
\hline & $\mathrm{D}$ & 0 & $0 \%$ & & & \\
\hline & $E$ & 5 & $100 \%$ & & & \\
\hline
\end{tabular}

$(\mathrm{N}=5)$

\section{DISCUSSION}

We found, both in the group treated conservatively and in the group treated with surgery, vertebral kyphosis with practically the same angles. Regional kyphosis was not present in any of the groups, but lordosis was preserved in the affected segment. ${ }^{8}$ The sagittal index (Farcy) remained within the parameters of stability for the lower lumbar segment, ${ }^{9}$ The percentage of loss of height and compression were similar following the treatment given to both groups, all following the system described by Escribá. ${ }^{10}$ The percentage of occupation of the canal is related to the type of fracture presented, although it is not related to the neurological deficit found in some of the patients. ${ }^{5}$

\section{CONCLUSIONS}

Patients who presented L4 fracture had satisfactory outcome in both treatment groups, which is reflected in the adequate bone fusion, preservation of vertebral body height, preservation of lordosis, and therefore of sagittal balance, enabling the mechanical functions of the vertebral spine to be restored in its entirety, unlike fractures in other segments.

Radiographic measurements confirm that this segment is less susceptible to collapse and kyphosis; neurological lesions are infrequent due to the amplitude of the neural canal, and environment of stability is maintained, due to the anatomical characteristics of this segment.

\section{ACKNOWLEDGEMENTS}

We thank the Spine Department of the Centro Medico Nacional de Occidente.

All authors declare no potential conflict of interest concerning this article.
6. Finn CA, Stauffer ES. Burst fracture of the fifth lumbar vertebra. J Bone Joint Surg Am. 1992;74(3):398-403.

7. An HS, Vaccaro A, Cotler JM, Lin S. Low lumbar burst fractures. Comparison among body cast, Harrington rod, Luque rod, and Steffee plate. Spine (Phila Pa 1976). 1991:16(Suppl 8):S440-4.

8. Wood K, Buttermann G, Mehbod A, Garvey T, et al. Operative compared with nonoperative treatment of a thoracolumbar burst fracture without neurological deficit. A prospective, randomized study. J Bone Joint Surg AM 2003; 85-A(5):773-81.

9. Farcy JP, Weidenbaum M and Glassman Sd. Sagittal index in management of thoracolumbar burst fractures. Spine 1990:15(9):958-65.

10. Escribá-Urios I, Escribá-Roca I and Gomar F. Fracturas por estallido toracolumbares: pasado, presente y future. Rev Esp Cir Osteoart 2006; 42 (227): 122-30. 